\title{
Fertilization of high-yield corn with poultry litter based on nitrogen doses
}

\author{
Juliano Corulli Corrêa(1), Marco André Grohskopf ${ }^{(2)}$, \\ Agostinho Rebellatto ${ }^{(3)}$, Amanda Zolet Rigo(4) and Arlei Coldebella(1)
}

\begin{abstract}
(1)Embrapa Suínos e Aves, BR 153, Km 110, Caixa Postal 321, CEP 89715-899 Concórdia, SC, Brazil. E-mail: juliano.correa@embrapa.br, arlei.coldebella@embrapa.br (2)Universidade Estadual Paulista, Faculdade de Ciências Agronômicas, Rua José Barbosa de Barros, no 1.780, CEP 18160-307 Botucatu, SP, Brazil. E-mail: marcogrohskopf@gmail.com ${ }^{(3)}$ Instituto Federal Catarinense, Campus Concórdia, SC 283, Km 08, CEP 89703-720 Concórdia, SC, Brazil. E-mail: agostinho.rebellatto@ifc-concordia.edu.br (4)Universidade do Estado de Santa Catarina, Avenida Luiz de Camões, o 2.090, Conta Dinheiro, CEP 88520-000 Lages, SC, Brazil. E-mail: amanda.z.rigo@gmail.com
\end{abstract}

\begin{abstract}
The objective of this work was to recommend nitrogen doses from poultry litter-based organic fertilizers in powder and pellet forms, compared with mineral fertilizer, in a high-yield corn crop under notillage. The treatments consisted of a $3 \times 3+1$ factorial arrangement, with: three fertilizers, two organic derived from poultry litter in powder $(\mathrm{OPo})$ and pelletized $(\mathrm{OPe})$ forms and one mineral fertilizer $(\mathrm{M})$; three $\mathrm{N}$ doses of 65,100 , and $135 \%$ of the recommended $\mathrm{N}$ requirement for corn; and an unfertilized control. After five corn crops farmed under no-tillage in a Rhodic Kandiudox, the recommended doses for fertilization with poultry litter organic fertilizers, with an expected yield equal to or greater than $8,000 \mathrm{~kg} \mathrm{ha}^{-1}$, could be achieved from doses of $100 \mathrm{~kg} \mathrm{ha}^{-1} \mathrm{~N}$ in OPe and $\mathrm{M}$ and of $121 \mathrm{~kg} \mathrm{ha}^{-1} \mathrm{~N}$ in OPo. Increasing doses of the OPe, OPo, and $\mathrm{M}$ fertilizers raise the contents of organic carbon, $\mathrm{N}$, and available $\mathrm{P}$ in the surface soil layer $(0.0-0.1 \mathrm{~m})$ and of exchangeable $\mathrm{K}$ up to a depth of $0.2 \mathrm{~m}$, allowing to obtain $\mathrm{N}$, $\mathrm{P}$, and $\mathrm{K}$ contents in the plant tissue within the sufficiency range of the corn crop.

Index terms: no-tillage farming, organic waste, pelletized fertilizer, powder fertilizer.

\section{Adubação de milho de alto rendimento com cama de aves tendo como critério o nitrogênio}

\begin{abstract}
Resumo - O objetivo deste trabalho foi recomendar doses de nitrogênio a partir de fertilizantes orgânicos produzidos com cama de aves, nas formas farelada e peletizada, em comparação ao fertilizante mineral, na cultura do milho de alto potencial produtivo, em sistema plantio direto. Os tratamentos foram dispostos em arranjo fatorial $3 \times 3+1$, com: três fertilizantes, dois orgânicos com cama de aves nas formas farelada (OF) e peletizada (OP) e um mineral (M); três doses de nitrogênio de 65,100 e $135 \%$ da necessidade de N recomendada para milho; e controle sem adubação. Após cinco safras de milho em sistema plantio direto, em Nitossolo Vermelho distroférrico, as doses recomendadas para adubação com fertilizantes orgânicos a partir de cama de aves, com expectativa de produtividade igual ou superior a $8.000 \mathrm{~kg} \mathrm{ha}^{-1}$, poderá ser realizada a partir das doses de $100 \mathrm{~kg} \mathrm{ha}^{-1}$ de $\mathrm{N}$ na forma de OP e M e $121 \mathrm{~kg} \mathrm{ha}^{-1}$ de $\mathrm{N}$ na OF. Doses crescentes dos fertilizantes OP, OF e M elevam os teores de carbono orgânico, $\mathrm{N}$ e $\mathrm{P}$ disponível no solo, na camada superficial $(0,0-0,1 \mathrm{~m})$, e de $\mathrm{K}$ trocável até $0,2 \mathrm{~m}$, o que permite obter teores de $\mathrm{N}, \mathrm{P}$ e K no tecido vegetal dentro da faixa de suficiência na cultura do milho.
\end{abstract}

Termos para indexação: plantio direto, resíduo orgânico, fertilizante peletizado, fertilizante farelado.

\section{Introduction}

Of all farming practices, the use of correctives and fertilizers is the most important in terms of increasing productivity and minimizing the farmed area (FAO, 2013). For this reason, highly soluble mineral fertilizers have been given considerable attention compared with organic fertilizers (Lopes \& Guilherme, 2016). Adequate nutrient management is currently necessary to meet the nutritional requirements imposed by the high extraction and exportation of new genetic material with yield potential in corn (Zea mays L.) (Resende et al., 2016b). This is a challenging scenario regarding progress in fertilization strategies and a possible review of critical nutrient levels.

Fertilization doses should be carefully recommended, especially for traditional systems, as they offer greater buffer in terms of nutrient stocks, due 
to the role of soil organic matter (SOM) conservation, complicating the interpretations of soil fertility (Sá et al., 2015). Excess fertilization causes "nutrient saturation" and subsequent fertilizations that do not correspond to gains in productivity, increasing the chance of nutritional losses and imbalances; however, not using any fertilization compromises nutrient stocks, limits the quantity and quality of SOM and the use of high-yield cultivars (Resende et al., 2016a).

Knowledge about the cycle of nutrients from organic fertilizers in traditional farming systems allows understanding the synchronism between nutrient release and plant demand (Hentz et al., 2016), both from a productivity point of view and in terms of reducing environmental risk (Grohskopf et al., 2016). This is important since the losses and additions of carbon and other nutrients modify the functioning of long-term farming system (Loss et al., 2011).

Of the organic fertilizers applied, poultry litter is the most commonly used byproduct of animal origin in the South of Brazil due to its abundance, price, and ease of use (Rogeri et al., 2016). Considering $16,243,286$ tons of litter are produced annually by the broiler poultry industry in the country (Diagnóstico..., 2012), estimated contributions of 568,515, 645,731, and 487,298 tons of $\mathrm{N}, \mathrm{P}_{2} \mathrm{O}_{5}$, and $\mathrm{K}_{2} \mathrm{O}$, respectively, are expected for the average contents of 35,40 , and $30 \mathrm{~g}$ $\mathrm{kg}^{-1} \mathrm{~N}, \mathrm{P}_{2} \mathrm{O}_{5}$, and $\mathrm{K}_{2} \mathrm{O}$ in dry matter. In other words, this raw material alone would be accountable for recycling 8.9 and $35 \%$, respectively, of the $\mathrm{N}$ used and produced in Brazil; these values are 12.5 and $25.6 \%$ for $\mathrm{P}_{2} \mathrm{O}_{5}$ and 5.2 and $57.3 \%$ for $\mathrm{K}_{2} \mathrm{O}$ (Anuário..., 2008).

It has been reported that the agronomic efficiency of organic fertilizers derived from poultry litter is equal or superior to that of soluble mineral products in no-tillage systems (Endale et al., 2010; Hentz et al., 2016).

Long-term studies have also shown that poultrylitter based organic fertilizers applied to corn crops increased yield and sustainability in the system (Scherer \& Nesi, 2009; He et al., 2016; Adeli et al., 2017). In this context, the present work seeks to define technical criteria to fertilize high-yield corn cultivars with poultry litter, without it being considered a potential environmental pollutant.

The objective of this work was to recommend nitrogen doses from poultry litter-based organic fertilizers in powder and pellet forms, compared with mineral fertilizer, in a high-yield corn crop under no-tillage.

\section{Materials and Methods}

The experiment was conducted in field conditions from 2010 to 2015, at the experimental unit of Embrapa Suínos e Aves, in the municipality of Concórdia, in the state of Santa Catarina, Brazil $\left(27^{\circ} 14^{\prime} 2^{\prime \prime} \mathrm{S}, 52^{\circ} 1^{\prime} 40^{\prime \prime} \mathrm{W}\right.$, at $569 \mathrm{~m}$ altitude). The climate of the region is $\mathrm{Cfa}$, according to Köppen's classification. The monthly mean rainfall and maximum and minimum air temperatures during the experiment are shown in Figure 1. The soil of the area is classified as a Nitossolo Vermelho distroférrico (Santos et al., 2013), i.e., a Rhodic Kandiudox, and presented the following initial chemical characteristics in the 0.0-0.2-m layer: $\mathrm{pH} 5.0$ in $\mathrm{H}_{2} \mathrm{O} ; 19 \mathrm{~g} \mathrm{dm}^{-3}$ organic $\mathrm{C} ; 60,35,15$, and $40 \mathrm{mmol}_{\mathrm{c}}$ $\mathrm{dm}^{-3} \mathrm{Ca}, \mathrm{Mg}, \mathrm{K}$, and $\mathrm{H}+\mathrm{Al}$, respectively; $35 \mathrm{mg} \mathrm{dm}^{-3}$ P; $1.2 \mathrm{~g} \mathrm{dm}^{-3}$ soil density; and $50 \%$ base saturation. Prior to installing the experiment, liming was carried out with $2 \mathrm{Mg}^{-1}$ dolomitic limestone and 75\% PRNT, applied to the soil surface with the purpose of raising base saturation to $70 \%$.

The experimental design was a randomized complete block in a $3 \times 3+1$ factorial arrangement, with four replicates, and the experimental unit consisted of a total area of $5 \times 6 \mathrm{~m}$ and a usable area of $3.2 \times 4$ $\mathrm{m}$. Increasing $\mathrm{N}$ doses $(0,65,100$, and $135 \%$ of the recommended $\mathrm{N}$ dose for a high-yield corn crop) were applied via three types of fertilizers (treatments): two poultry-litter based organic fertilizers in powder (OPo) and pellet $(\mathrm{OPe})$ forms, compared with a mineral (M) fertilizer composed of soluble urea, single superphosphate and potassium chloride; all fertilizers had the same N, P, and K contents. It should be noted that the recommended dose is $90 \mathrm{~kg} \mathrm{~N}$ for corn with an expected yield of $8 \mathrm{Mg} \mathrm{ha}^{-1}$, according to Silva et al. (2016).

The mineral fertilizer was incorporated in the furrow alongside and under $(0.05 \mathrm{~m})$ the seeds, whereas the organic fertilizers (OPo and $\mathrm{OPe}$ ) were applied to the soil surface. For all treatments, the pre-established single doses were applied during corn sowing.

The OPo and OPe fertilizers were derived from the litter of six batches of poultry, each with 42 days, composed of $2.0,1.5$, and $1.0 \mathrm{~g} \mathrm{~kg}^{-1}$ total $\mathrm{N}, \mathrm{P}$, and $\mathrm{K}$ on a dry basis, with similar breakdown for all years of planting. Before being used for the production of the powder and pelleted fertilizers, the poultry litter underwent a 25-day compost process, being revolved whenever the interior reached a temperature of $50^{\circ} \mathrm{C}$; 
once the temperature had stabilized, the litter was seived through a 4-mm mesh screen to produce the powder fertilizer or sent to a pellet extruder to make $1.5-\mathrm{cm}$ long and $0.5 \mathrm{~cm}$-wide fertilizer pellets.

In summer, the following single hybrids of corn were sown: DKB 240 yieldgard in 2011/2012; AG 8060 YG in 2012/2013; and Syngenta in 2013/2014, 2014/2015, and 2015/2016, at a spacing of $0.80 \mathrm{~m}$ between the lines, with 5.3 seeds per meter for a population of 60,000 plants per hectare. In the winter of 2013, 2014, and 2015, white oat (Avena sativa L.) was sown as a cover crop, without fertilization, at a density of $50 \mathrm{~kg} \mathrm{ha}^{-1}$, with approximately 80 seeds per linear meter, and at a spacing of $0.20 \mathrm{~m}$ between lines. The winter plants were desiccated 14 days prior to the planting season of the summer crops, using of $1,800 \mathrm{~g} \mathrm{ha}^{-1}$ a.i. glyphosate, and invasive plants were controlled manually during the initial stages of crop cultivation.

In the 2011/2012, 2012/2013, 2013/2014, 2014/2015, and 2015/2016 crop years two rows of corn were harvested manually, each $2 \mathrm{~m}$ long and with 0.8 $\mathrm{m}$ between rows, totaling $3.2 \mathrm{~m}^{2}$ of usable area. In sequence, the following procedures were carried out: manual threshing, weighing and subsequent drying of wet grains, and separating the chaff and grains. Once the weight of the harvested grains was determined, yield was calculated, by applying a 13\% moisture correction value.

To determine the total levels of $\mathrm{N}, \mathrm{P}$, and $\mathrm{K}$ in the tissue, 30 leaves were collected from the middle third opposite of and below the cob, during the bolting phase of corn (50\% of plants bolted), according to Silva et al. (2016). The plant tissue samples collected were dried in an oven with forced-air circulation at $65^{\circ} \mathrm{C}$ until reaching constant weight. The material was subsequently ground to determine the total concentrations of $\mathrm{N}, \mathrm{P}$, and $\mathrm{K}$, as described by Tedesco et al. (1995).

Soil sampling was conducted at the end of the corn crop cycle, in 2016, in the fifth year of the experiment, at the depths of $0.0-0.1,0.1-0.2$, and $0.2-0.4$ m. Random soil

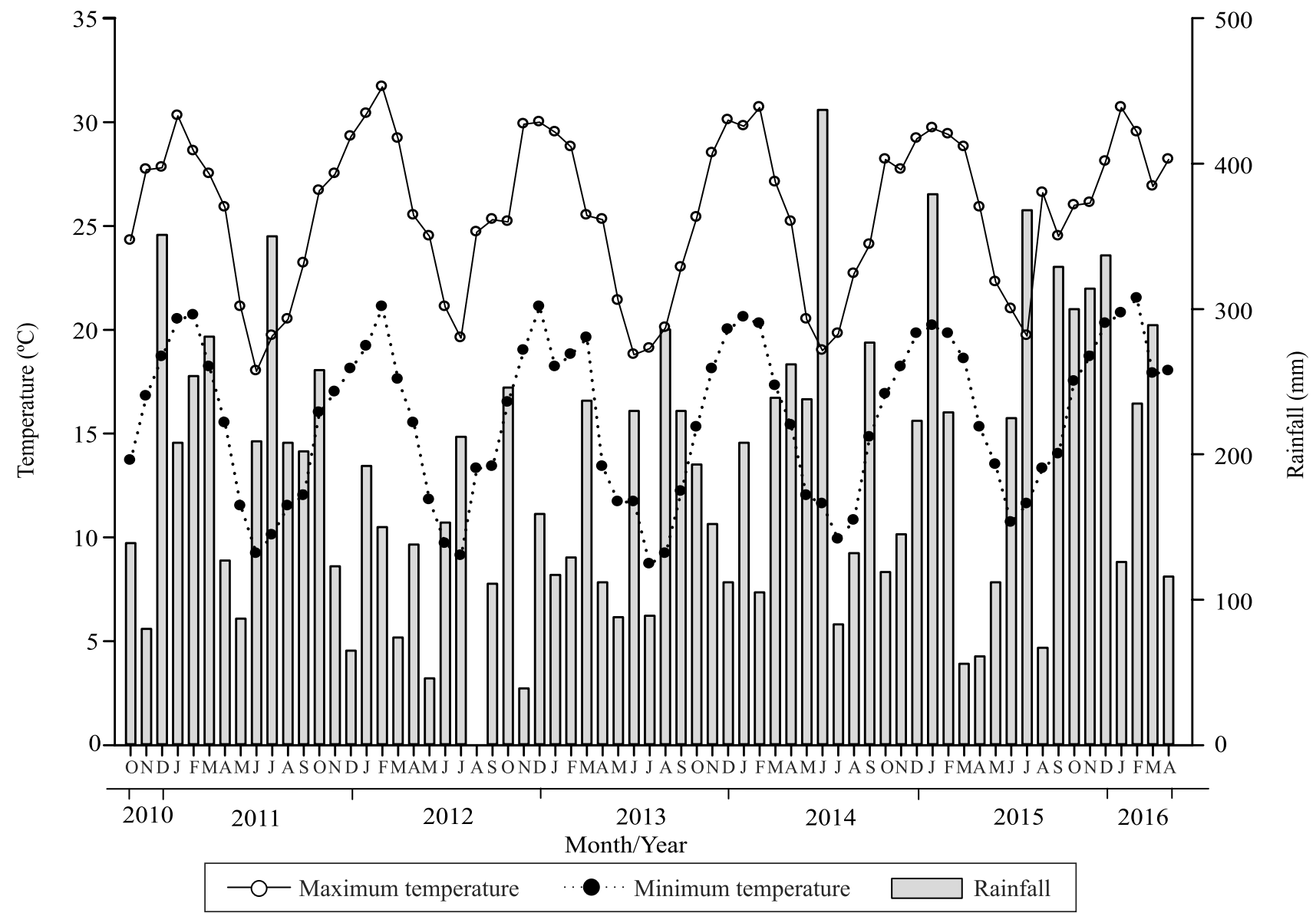

Figure 1. Mean monthly rainfall and maximum and minimum temperatures during the experimental period from 2010 and 2016. 
samples were taken, two in between rows and one on the row for each layer, forming a composite sample, which was air-dried and screened in a 2-mm mesh. The sample was then subjected to chemical analysis to determine organic carbon, total $\mathrm{N}$, available $\mathrm{P}$, and exchangeable $\mathrm{K}$, according to Tedesco et al. (1995).

The data were analyzed for homogeneity and normal distribution, and no data transformation was required. The treatment means were then compared by Tukey's test, at $5 \%$ probability, protected by the significance of a global F-test. Furthermore, the regression analysis was performed to determine the behavior of the variables in response to the applied doses of the organic and mineral fertilizers.

\section{Results and Discussion}

In the high-yield corn farmed under a no-tillage system (NTS) for five years, increasing doses of $\mathrm{N}$ from the OPo and OPe had a direct relationship with soil organic carbon (SOC) content. From the $100 \%$ dosage onwards, both fertilizers were only more efficient than the mineral one in the $0.0-0.01-\mathrm{m}$ layer (Table 1).

After five years, the application of the organic fertilizers at the recommended dosage of $135 \%$ of $\mathrm{N}$ for corn promoted increases of up to $25 \%$ in the SOC

Table 1. Mean organic carbon content, evaluated in 2016, in three soil layers in response to increasing nitrogen doses $(0,65,100$, and $135 \%$ of the recommended $\mathrm{N}$ dose), applied via poultry litter-based organic fertilizers in pellet (OPe) and powder $(\mathrm{OPo})$ forms, compared with a mineral fertilizer $(\mathrm{M})$, after five corn (Zea mays) harvests in a no-tillage system ${ }^{(1)}$.

\begin{tabular}{|c|c|c|c|c|c|c|}
\hline \multirow[t]{2}{*}{ Fertilizer } & \multicolumn{4}{|c|}{ Organic carbon $\left(\mathrm{mg} \mathrm{dm}^{-3}\right)$} & \multirow[t]{2}{*}{ Regression equation ${ }^{(2)}$} & \multirow[t]{2}{*}{$\mathrm{R}^{2}$} \\
\hline & 0 & 65 & 100 & 135 & & \\
\hline & \multicolumn{4}{|c|}{$0.0-0.1 \mathrm{~m}$} & & \\
\hline $\mathrm{OPe}$ & 21 & 25 & $28 \mathrm{~A}$ & $28 \mathrm{~A}$ & $\hat{y}=21+0.09 x+0.0002 x^{2}$ & 0.86 \\
\hline OPo & 21 & 24 & $28 \mathrm{~A}$ & $27 \mathrm{~A}$ & $\hat{y}=21+0.08 x+0.0002 x^{2}$ & 0.91 \\
\hline \multirow[t]{2}{*}{ M } & 21 & 24 & 24B & $22 \mathrm{~B}$ & $\overline{\mathrm{y}}=22$ & \\
\hline & \multicolumn{4}{|c|}{$0.1-0.2 \mathrm{~m}$} & & \\
\hline $\mathrm{OPe}$ & 16 & 18 & 19 & 18 & $\bar{y}=18$ & \\
\hline OPo & 16 & 17 & 18 & 18 & $\bar{y}=17$ & \\
\hline \multirow[t]{2}{*}{ M } & 16 & 18 & 18 & 18 & $\bar{y}=18$ & \\
\hline & \multicolumn{4}{|c|}{$0.2-0.4 \mathrm{~m}$} & & \\
\hline $\mathrm{OPe}$ & 15 & 17 & 17 & 18 & $\bar{y}=17$ & \\
\hline OPo & 15 & 16 & 17 & 16 & $\bar{y}=16$ & \\
\hline M & 15 & 17 & 18 & 16 & $\bar{y}=16$ & \\
\hline
\end{tabular}

(1) Means of four replicates followed by equal letters, lowercase in the lines and uppercase in the columns, do not differ by Tukey's test, at $5 \%$ probability. (2) Regression equations significant at $1 \%$ probability. $\mathrm{R}^{2}$, coefficient of determination. content in relation to the mineral fertilizer (Table 1). Similar were obtained by Adeli et al. (2007), who found an increase of $20 \%$ in SOC after $6.7 \mathrm{Mg} \mathrm{ha}^{-1}$ poultry litter were applied annually under three years, compared with a mineral fertilizer, in a traditional soil management system. Watts et al. (2010) reported SOC contents of 2.2 and $1.8 \mathrm{~g} \mathrm{~kg}^{-1}$ in corn and soybean crops with poultry litter fertilization, but 1.7 and $1.1 \mathrm{~g} \mathrm{~kg}^{-1}$ for the same crops with mineral fertilization, at a depth of $0.0-0.05 \mathrm{~m}$.

Considering total $\mathrm{N}$, a direct relationship was only observed between $\mathrm{N}$ content and doses in the layer of 0.0-0.1 $\mathrm{m}$ (Table 2). In addition, there was a greater linear coefficient for the organic fertilizers than for the mineral one, but no difference between the fertilizers within the same dosage. In organic fertilization, $\mathrm{N}$ reactions differ from those of the mineral sources; for example, mineralization was slower in poultry litter, which favors microbial activity and immobilization components, allowing the momentary reduction in the transformation of $\mathrm{N}$ into inorganic forms momentary (Müller et al., 2011). Schomberg et al. (2011) found that the application of poultry litter in no-tillage farming increases the efficacy of $\mathrm{N}$ mineralization in the soil and improves the synchrony of nutrient availability throughout the corn crop cycle, when compared with the mineral source.

Table 2. Mean total nitrogen content, evaluated in 2016, in three soil layers in response to increasing nitrogen doses $(0$, 65,100 , and $135 \%$ of the recommended $\mathrm{N}$ dose), applied via poultry litter-based organic fertilizers in pellet (OPe) and powder (OPo) forms, compared with a mineral fertilizer (M), after five corn (Zea mays) harvests in a no-tillage system ${ }^{(1)}$.

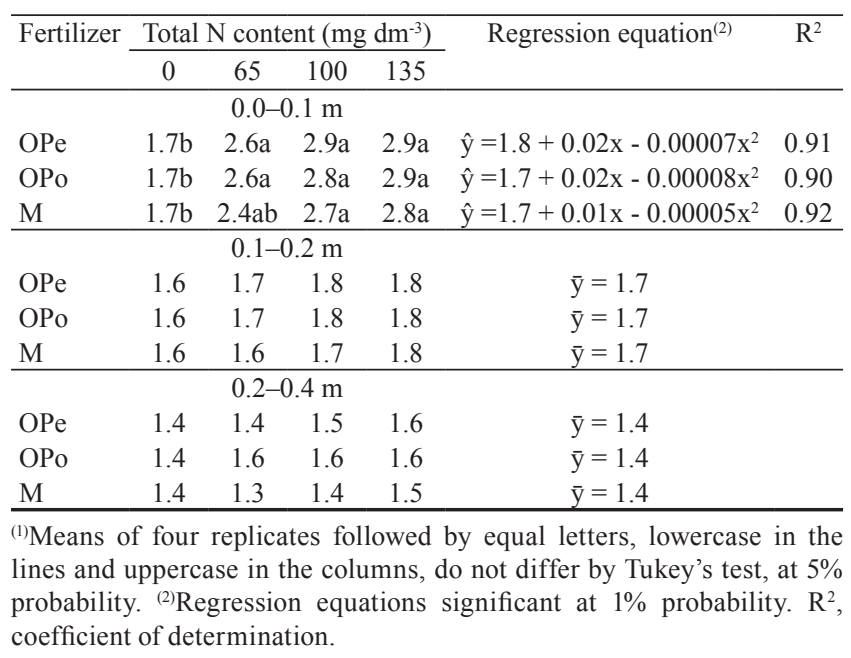

Pesq. agropec. bras., Brasília, v.53, n.3, p.342-350, Mar. 2018 DOI: 10.1590/S0100-204X2018000300009 
For the total $\mathrm{N}$ content in the soil, the most effective doses were 142, 125, and $100 \%$ for OPe, OPo, and the mineral fertilizer (Table 2), respectively, with the greatest linear coefficients for $\mathrm{OPo}$ and $\mathrm{OPe}$ being related to the differentiated $\mathrm{N}$ liberation rate into the system, which is dependent on the degree of polymerization of the organic components (Grohskopf et al., 2015). The lower coefficient is a consequence of its supply in amide form $\left(\mathrm{CO}\left(\mathrm{NH}_{2}\right)_{2}\right)$, which after ammonification and nitrification is rapidly transformed into a nitrate $\left(\mathrm{N}^{-} \mathrm{NO}_{3}{ }^{-}\right)$, a form of $\mathrm{N}$ that is scarcely absorbed into the soil colloids, remaining almost exclusively in the soil solution, and that is subject to losses through leaching or denitrification (Zhang et al., 2011) if not absorbed by the plants.

In relation to available $\mathrm{P}$ in the soil, a response was observed only in the layer of $0.0-0.1 \mathrm{~m}$, with an increasing quadratic behavior for $\mathrm{OPe}$ and an increasing linear behavior for OPo and the mineral fertilizer; the most effective doses were $91 \%$ for OPe and $135 \%$ for OPo and the mineral fertilizer (Table 3). Between fertilizers, a difference was only verified at the dose of $135 \%$ of recommended $\mathrm{N}$, in alignment with the following order of magnitude: $\mathrm{OPo} \geq$ mineral fertilizer $>\mathrm{OPe}$. These results corroborate those of Scherer \& Nesi (2009) and Hentz et al. (2016), who observed increased available $\mathrm{P}$ in function of poultry

Table 3. Mean phosphorus availability, evaluated in 2016, in three soil layers in response to increasing nitrogen doses $(0,65,100$, and $135 \%$ of the recommended $n$ dose $)$, applied via poultry litter-based organic fertilizers in pellet (OPe) and powder (OPo) forms, compared with a mineral fertilizer (m), after five corn (Zea mays) harvests in a no-tillage system ${ }^{(1)}$.

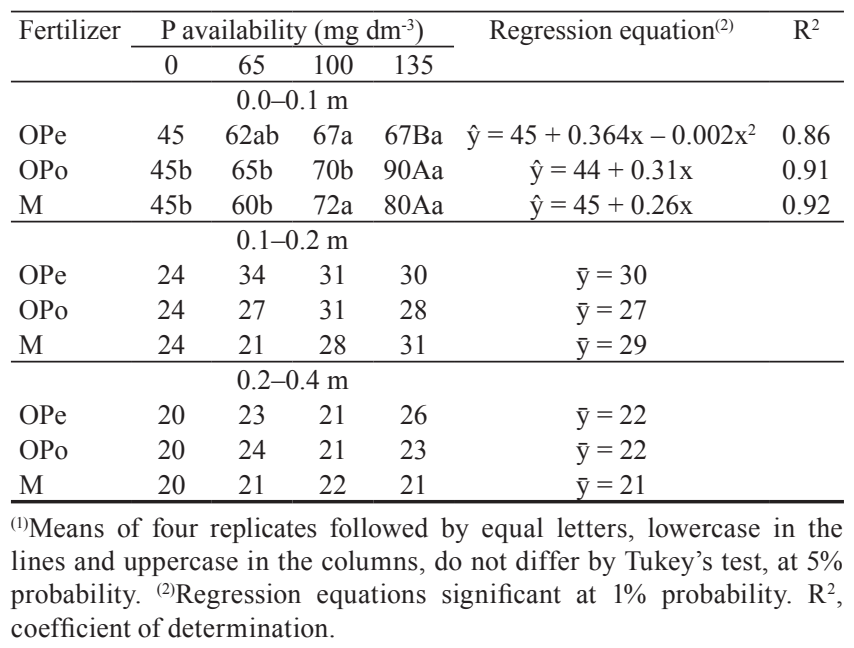

litter fertilization in NTS and integrated crop-livestock system for corn production.

The concentration of $\mathrm{P}$ in the soil-plant system promoted increased available $\mathrm{P}$ to a depth of $0.1-0.2$ $\mathrm{m}$, starting at the dose of $65 \%$ for the organic fertilizers (OPe and OPo) and of 100\% for the mineral one (Table 3). These results are justified by the competition between organic anions and $\mathrm{P}$ for the same soil absorption sites, which enables increased nutrient availability and subsequent displacement with depth (Shuai \& Zinati, 2009).

The response to available $\mathrm{P}$ content on soil surface is related to absorption reactions and rainfall, which control the destination of the $\mathrm{P}$ from the fertilizers, especially its absorption in soils of oxydic character, due to the high covalent bonding energy between the phosphate anion and the functional groups on mineral surface (Montalvo et al., 2015). The continued application of poultry litter to the soil in NTS for long-term corn production increases the available $\mathrm{P}$ content in the soil; therefore, excessive doses can lead to environmental risks (Endale et al., 2010).

For the level of exchangeable $\mathrm{K}$ in the soil, a quadratic behavior was observed in function of the fertilizers to a depth of $0.2 \mathrm{~m}$, and no significant difference was verified between fertilizers for the same dose (Table 4).

Table 4. Mean exchangeable potassium content, evaluated in 2016, in three soil layers in response to increasing nitrogen doses $(0,65,100$, and $135 \%$ of the recommended $\mathrm{N}$ dose), applied via poultry litter-based organic fertilizers in pellet (OPe) and powder (OPo) forms, compared with a mineral fertilizer (M), after five corn (Zea mays) harvests in a no-tillage system ${ }^{(1)}$.

\begin{tabular}{|c|c|c|c|c|c|c|}
\hline \multirow{2}{*}{$\begin{array}{l}\text { Fer- } \\
\text { tilizer }\end{array}$} & \multicolumn{4}{|c|}{ Exchangeable $\mathrm{K}\left(\mathrm{mg} \mathrm{dm}^{-3}\right)$} & \multirow[t]{2}{*}{ Regression equation $^{(2)}$} & \multirow[t]{2}{*}{$\mathrm{R}^{2}$} \\
\hline & 0 & 65 & 100 & 135 & & \\
\hline \multicolumn{7}{|c|}{$0.0-0.1 \mathrm{~m}$} \\
\hline $\mathrm{OPe}$ & 6 & 10 & 13 & 13 & $\hat{y}=6.0+0.009 x-0.0003 x^{2}$ & 0.91 \\
\hline OPo & 6 & 13 & 14 & 13 & $\hat{y}=27+0.06 x-0.00007 x^{2}$ & 0.76 \\
\hline M & 6 & 13 & 13 & 12 & $\hat{y}=27+0.16 x-0.001 x^{2}$ & 0.77 \\
\hline \multicolumn{7}{|c|}{$0.1-0.2 \mathrm{~m}$} \\
\hline $\mathrm{OPe}$ & 8 & 9 & 11 & 10 & $\hat{y}=8.2+0.03 x-0.0001 x^{2}$ & 0.68 \\
\hline OPo & 8 & 10 & 12 & 10 & $\hat{y}=8.1+0.05 x-0.0003 x^{2}$ & 0.76 \\
\hline M & 8 & 9 & 11 & 12 & $\hat{y}=8.2+0.02 x+0.00007 x^{2}$ & 0.75 \\
\hline \multicolumn{7}{|c|}{$0.2-0.4 \mathrm{~m}$} \\
\hline $\mathrm{OPe}$ & 8 & 8 & 9 & 9 & $\bar{y}=8$ & \\
\hline OPo & 8 & 6 & 9 & 9 & $\bar{y}=8$ & \\
\hline M & 8 & 6 & 8 & 8 & $\bar{y}=8$ & \\
\hline
\end{tabular}

(1) Means of four replicates followed by equal letters, lowercase in the lines and uppercase in the columns, do not differ by Tukey's test, at $5 \%$ probability. ${ }^{(2)}$ Regression equations significant at $1 \%$ probability. $\mathrm{R}^{2}$, coefficient of determination. 
The values obtained for exchangeable $\mathrm{K}$ in the soil remained in the range considered "very high" in the treatments where this nutrient was supplied, but were reduced in the control treatment, compared with the initial analysis.

The displacement of $\mathrm{K}$ to a depth of $0.1-0.2 \mathrm{~m}$ due to organic or mineral fertilization is related to lowenergy ionic bonds formed in the soil by this nutrient with mineral surfaces or organic compounds that have a negative load (Kaminski et al., 2010). This condition allows increased mobility and the accumulation of $\mathrm{K}$ at deeper levels if not absorbed by the plants, especially in predominantly argilomineral soils of type 1:1 in the forms of kaolinite and of the $\mathrm{Fe}$ and $\mathrm{Al}$ oxides, abundant in Nitisols.

An increasing response was verified for corn grain yield in function of increasing doses of the mineral fertilizer and OPo and OPe (Table 5). In the 2011/2012 crop, a quadratic behavior was observed for OPe and the mineral fertilizer, and a linear behavior for OPo, whereas, in 2012/2013, there was quadratic behavior for OPe and a linear one for OPo and the mineral fertilizer. In the 2013/2014, 2014/2015, and 2015/2016 harvests, a linear behavior was verified in function

Table 5. Corn (Zea mays) grain yield in response to increasing nitrogen doses $(0,65,100$, and $135 \%$ of the recommended $\mathrm{N}$ dose), applied via organic and mineral fertilizers, in a no-tillage system ${ }^{(1)}$.

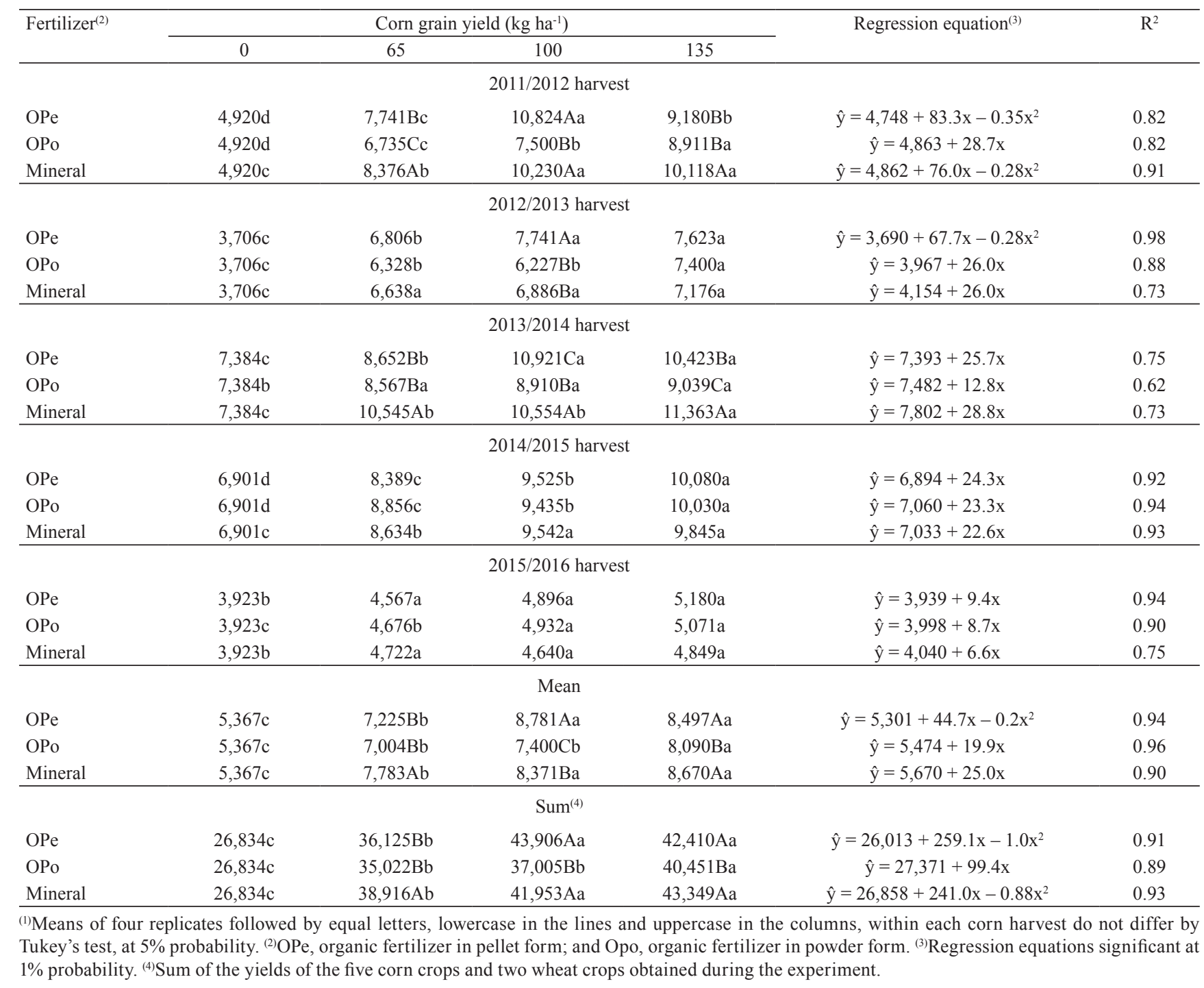


of the increasing doses of OPe, OPo, and the mineral fertilizer. The frequent and ongoing application of poultry litter over a long period of time in NTS has increased yield in corn crops: up to $42 \%$ against $27 \%$ when there was no organic fertilization (Endale et al., 2010), and the addittion of 2,608 $\mathrm{kg} \mathrm{ha}^{-1}$ with $42 \mathrm{~kg} \mathrm{ha}^{-1}$ $\mathrm{N}$ in NTS under eroded soil (Adeli et al., 2017).

In the 2012/2013 and 2015/2016 harvests, there was a serious decline in the yield of the corn plants due to the lack of rainfall (Figure 1) in the initial period of growth and development, primarily during germination and emergence. These results may be related to the infiltration, storage, and availiability of water in the soil, responsible for the displacement of nutrients in the system, interfering directly in soil fertility and its effects on plants.

Among the fertilizers, the mineral one showed the greatest efficiency at the doses of 65 and $100 \%$ in the 2011/2012 harvest, and, at all doses, in the 2013/2014 harvest; OPe was superior to the others at the $100 \%$ dose in the 2012/2013 harvest (Table 5). From the fourth harvest onwards, the fertilizers were similar due to the high soil fertility, shown here by the chemical analyses of C, N, P, and K after six years of farming (Tables 1, 2, 3 , and 4). When the chemical properties are preserved or improved over time, it is possible to achieve high corn yield in NTS (Nicolodi et al., 2008).

The mean of the five corn yields showed a growing response in function of the applied doses, with a quadratic behavior for $\mathrm{OPe}$ and a linear one for OPo and the mineral fertilizer (Table 5). Considering that $90 \mathrm{~kg} \mathrm{ha}^{-1} \mathrm{~N}$ are required for an expected yield of 8 $\mathrm{Mg} \mathrm{ha}^{-1}$ (Silva et al., 2016), $100 \mathrm{~kg} \mathrm{ha}^{-1} \mathrm{~N}$ via OPe and $121 \mathrm{~kg} \mathrm{ha}^{-1} \mathrm{~N}$ via OPo and the mineral fertilizer could be recommended for corn crops based on an average production of five corn harvests in NTS. The need to apply a greater amount of OPo than OPe may be due to the greater surface contact between the powder fertilizer and the soil, which increases its reaction, explaining its lower efficiency.

An increasing quadratic behavior was observed for the $\mathrm{N}, \mathrm{P}$, and $\mathrm{K}$ contents in the tissue of the diagnosed corn leaf in function of the application of increasing doses of $\mathrm{N}$ via $\mathrm{OPe}, \mathrm{OPo}$, and the mineral fertilizer; doses only differed regarding $\mathrm{N}$ and $\mathrm{K}$ contents, and only the $0 \%$ dose differed from the others in $\mathrm{OPe}, \mathrm{OPo}$, and the mineral fertilizer (Table 6). The N, P, and $\mathrm{K}$ contents in the tissue, based on mean values obtained
Table 6. Mean content of nitrogen, phosphorus, and total potassium in the diagnosed corn (Zea mays) leaf for five harvests in response to increasing nitrogen doses $(0,65$, 100 , and $135 \%$ of the recommended $\mathrm{N}$ dose), applied via organic and mineral fertilizers, in a no-tillage system ${ }^{(1)}$.

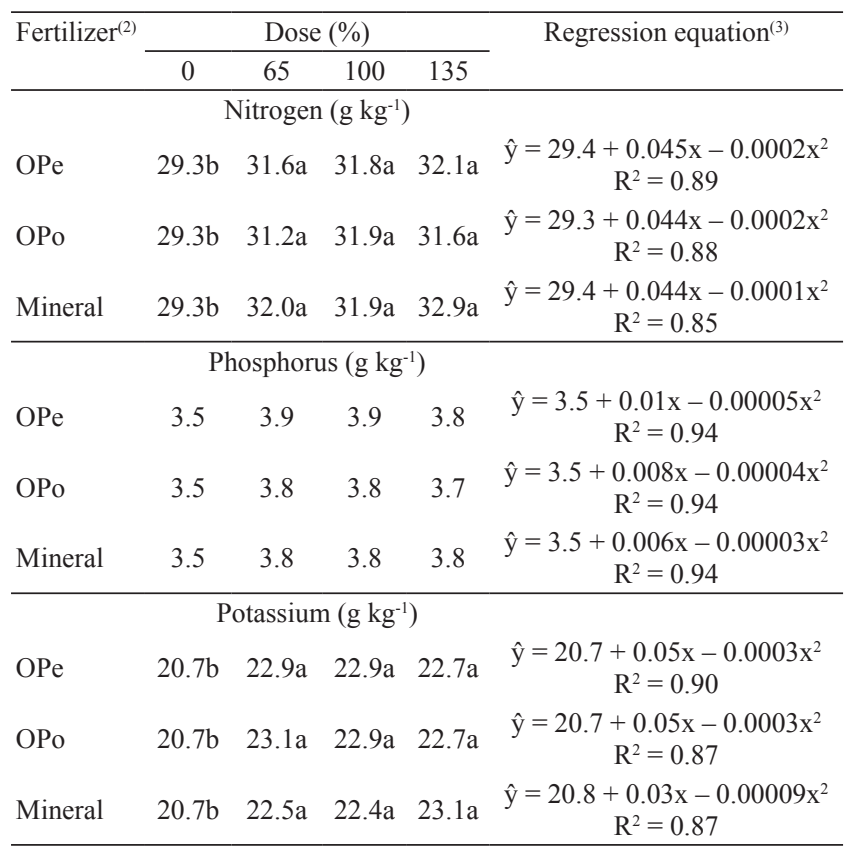

${ }^{(1)}$ Means followed by equal letters, lowercase in the lines and uppercase in the columns, represent the difference within each element and do not differ by Tukey's test, at $5 \%$ probability. ${ }^{(2)} \mathrm{OPe}$, organic fertilizer in pellet form; and Opo, organic fertilizer in powder form. ${ }^{(3)}$ Regression equations significant at $1 \%$ probability. The suffciency range in the tissue of the diagnosed corn leaf is: $27-35,2-4$, and $17-35 \mathrm{~g} \mathrm{~kg}^{-1} \mathrm{~N}, \mathrm{P}$, and $\mathrm{K}$, respectively, according to Tedesco et al. (2004).

over five years, remained within the range considered adequate for the crop, i.e., 27-35, 2-4, and 17-35 $\mathrm{g} \mathrm{kg}^{-1}$ for $\mathrm{N}, \mathrm{P}$, and $\mathrm{K}$, respectively, according to Silva et al. (2016), which is explained by the fact that the soil at the start of the experiment already showed built-up fertility.

\section{Conclusions}

1. After five corn (Zea mays) crops farmed under a no-tillage system in a Rhodic Kandiudox, the recommended fertilization with poultry-litter based organic fertilizers, with an expected yield equal to or greater than $8,000 \mathrm{~kg} \mathrm{ha}^{-1}$, can be achieved from doses of $100 \mathrm{~kg} \mathrm{ha}^{-1} \mathrm{~N}$ in pelletized (OPe) and mineral forms and of $121 \mathrm{~kg} \mathrm{ha}^{-1} \mathrm{~N}$ in powder (OPo). 
2. Increasing doses of $\mathrm{OPe}, \mathrm{OPo}$, and mineral fertilizers raised the contents of organic carbon, $\mathrm{N}$, and available $P$ in the surface soil layer $(0.0-0.1 \mathrm{~m})$ and of exchangeable $\mathrm{K}$ to a depth of $0.2 \mathrm{~m}$, allowing to obtain $\mathrm{N}, \mathrm{P}$, and $\mathrm{K}$ contents in the plant tissue within the sufficiency range for the corn crop.

3. The greater need for fertilization with OPo than OPe may be due to the greater surface contact between the powder fertilizer and soil, which increases its reaction and explains its lower efficiency.

\section{Acknowledgments}

To Terraplant in partnership with Empresa Brasileira de Pesquisa Agropecuária (Embrapa), for funding the laboratorial analyses and providing the organic fertilizer powders and pellets during the experiment.

\section{References}

ADELI, A.; DABNEY, S.M.; TEWOLDE, H.; JENKINS, J.N. Effects of tillage and broiler litter on crop productions in an eroded soil. Soil and Tillage Research, v.165, p.198-209, 2017. DOI: 10.1016/j.still.2016.08.010.

ADELI, A.; SISTANI, K.R.; ROWE, D.E.; TEWOLDE, H. Effects of broiler litter applied to no-till and tillage cotton on selected soil properties. Soil Science Society of America Journal, v.71, p.974983, 2007. DOI: 10.2136/sssaj2006.0092.

ANUÁRIO estatístico do setor de fertilizantes: 2008. São Paulo: Associação Nacional para Difusão de Adubos, 2008. 160 p.

DIAGNÓSTICO dos resíduos orgânicos do setor agrossilvopastoril e agroindústrias associadas. Brasília: Instituto Econômico de Pesquisa Aplicada, 2012. 129p. Relatório de pesquisa.

ENDALE, D.M.; SCHOMBERG, H.H.; JENKINS, M.B.; FRANKLIN, D.H.; FISHER, D.S. Management implications of conservation tillage and poultry litter use for Southern Piedmont USA cropping systems. Nutrient Cycling Agroecosystems, v.88, p.299-313, 2010. DOI: 10.1007/s10705-009-9318-z.

FAO. Food and Agriculture Organization of the United Nations. Relatório anual da Organização das Nações Unidas para a Alimentação e Agricultura. 2013. Available at: <http://sna.agr. br/roberto-rodrigues-sobre-o-relatorio-anual-da-fao-tecnologiaagricola-brasileira-aumentou-a-produtividade-por-area-epreservou-67-milhoes-de-hectares/>. Accessed on: Nov. 242016.

GROHSKOPF, M.A.; CASSOL, P.C.; CORRÊA, J.C.; ALBUQUERQUE, J.A.; ERNANI, P.R.; MAFRA, M.S.H.; MAFRA, Á.L. Soil solution nutrient availability, nutritional status and yield of corn grown in a typic hapludox under twelve years of pig slurry fertilizations. Revista Brasileira de Ciência do Solo, v.40, e0150341, 2016. DOI: 10.1590/18069657rbcs20150341.

GROHSKOPF, M.A.; CASSOL, P.C.; CORREA, J.C.; MAFRA, M.S.H.; PANISSON, J. Organic nitrogen in a typic hapludox fertilized with pig slurry. Revista Brasileira de Ciência do Solo, v.39, p.127-139, 2015. DOI: 10.1590/01000683rbcs20150080.

HE, Z.; PAGLIARI, P.H.; WALDRIP, H.M. Applied and environmental chemistry of animal manure: a review. Pedosphere, v.26, p.779-816, 2016. DOI: 10.1016/S1002-0160(15)60087-X.

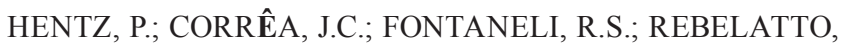
A.; NICOLOSO, R. da S.; SEMMELMANN, C.E.N. Poultry litter and pig slurry applications in an integrated crop-livestock system. Revista Brasileira de Ciência do Solo, v.40, e0150072, 2016. DOI: $10.1590 / 18069657$ rbcs20150072.

KAMINSKI, J.; MOTERLE, D.F.; RHEINHEIMER, D. dos S.; GATIBONI, L.C.; BRUNETTO, G. Potassium availability in a Hapludalf soil under long term fertilization. Revista Brasileira de Ciência do Solo, v.34, p.783-791, 2010. DOI: 10.1590/S010006832010000300020 .

LOPES, A.S.; GUILHERME, L.R.G. A career perspective on soil management in the Cerrado Region of Brazil. Advances in Agronomy, v.137,p.1-72,2016. DOI: 10.1016/bs.agron.2015.12.004.

LOSS, A.; PEREIRA, M.G.; GIÁCOMO, S.G.; PERIN, A.; SANTOS, L.H.C. dos. Agregação, carbono e nitrogênio em agregados do solo sob plantio direto com integração lavourapecuária. Pesquisa Agropecuária Brasileira, v.46, p.1269-1276, 2011. DOI: 10.1590/S0100-204X2011001000022.

MONTALVO, D.; DEGRYSE, F.; MCLAUGHLIN, M.J. Agronomic effectiveness of granular and fluid phosphorus fertilizers in andisols and oxisols. Soil Science Society of America Journal, v.79, p.577-584, 2015. DOI: 10.2136/sssaj2014.04.0178.

MÜLLER, C.; LAUGHLIN, R.J.; CHRISTIE, P.; WATSON, C.J. Effects of repeated fertilizer and cattle slurry applications over 38 years on $\mathrm{N}$ dynamics in a temperate grassland soil. Soil Biology and Biochemistry, v.43, p.1362-1371, 2011. DOI: 10.1016/j. soilbio.2011.03.014.

NICOLODI, M.; GIANELLO, C.; ANGHINONI, I.; MARRÉ, J.; MIELNICZUK, J. Insuficiência do conceito mineralista para expressar a fertilidade do solo percebida pelas plantas cultivadas no sistema plantio direto. Revista Brasileira de Ciência do Solo, v.32, p.2735-2744, 2008. DOI: 10.1590/S010006832008000700017.

RESENDE, A.V. de; FONTOURA, S.M.V.; BORGHI, E.; SANTOS, F.C. dos; KAPPES, C.; MOREIRA, S.G.; OLIVEIRA JUNIOR, A. de; BORIN, A.L.D.C. Solos de fertilidade construída: características, funcionamento e manejo. Informações Agronômicas, n.156, p.1-19, 2016a.

RESENDE, A.V. de; LACERDA, J.J. de J.; HICKMAN, C.; WILDA, L.R.M.; FURTINI NETO, A.E.; SILVA, C.A.; MOREIRA, S.G. Repensando a adubação NPK em sistemas de alta produtividade de grãos. In: MOREIRA F.M. de S.; KASUYA, M.C.M. (Ed.). Fertilidade e biologia do solo: integração e tecnologia para todos. Viçosa: Sociedade Brasileira de Ciência do Solo, 2016b. p.541-558.

ROGERI, D.A.; ERNANI, P.R.; MANTOVANI, A.; LOURENÇO, K.S. Composition of poultry litter in Southern Brazil. Revista Brasileira de Ciência do Solo, v.40, e0140697, 2016. DOI: 10.1590/18069657rbcs20140697. 
SÁ, J.C. de M.; SÉGUY, L.; TIVET, F.; LAL, R.; BOUZINAC, S.; BORSZOWSKEI, P.R.; BRIEDIS, C.; SANTOS, J.B. dos; HARTMAN, D. da C.; BERTOLONI, C.G.; ROSA, J.; FRIEDRICH, T. Carbon depletion by plowing and its restoration by no-till cropping systems in Oxisols of subtropical and tropical agro-ecoregions in Brazil. Land Degradation \& Development, v.26, p.531-543, 2015. DOI: 10.1002/ldr.2218.

SANTOS, H.G. dos; JACOMINE, P.K.T.; ANJOS, L.H.C. dos; OLIVEIRA, V.A. de; LUMBRERAS, J.F.; COELHO, M.R.; ALMEIDA, J.A. de; CUNHA, T.J.F.; OLIVEIRA, J.B. de. Sistema brasileiro de classificação de solos. 3.ed. rev. e ampl. Rio de Janeiro: Embrapa, 2013. 353p.

SCHERER, E.E.; NESI, C.N. Características químicas de um Latossolo sob diferentes sistemas de preparo e adubação orgânica. Bragantia, v.68, p.715-721, 2009. DOI: 10.1590/S000687052009000300019.

SCHOMBERG, H.H.; ENDALE, D.M.; JENKINS, M.B.; FISHER, D.S. Nutrient source and tillage influences on nitrogen availability in a Southern Piedmont corn cropping system. Biology and Fertility of Soils, v.47, p.823-831, 2011. DOI: 10.1007/s00374-011-0582-0.
SHUAI, X.; ZINATI, G. Proton charge and adsorption of humic acid and phosphate on goethite. Soil Science Society of America Journal, v.73, p.2013-2020, 2009. DOI: 10.2136/sssaj2009.0119.

SILVA, L. da S.; GATIBONI, L.C.; ANGHINONI, I.; SOUZA, R.O. (Ed.). Manual de calagem e adubação para os estados do Rio Grande do Sul e Santa Catarina. Porto Alegre: Sociedade Brasileira de Ciência do Solo, Núcleo Regional Sul, Comissão de Química e Fertilidade do Solo, 2016.376p.

TEDESCO, M.J.; GIANELLO, C.; BISSANI, C.A.; BOHNEN, H.; VOLKWEISS, S.J. Análises de solo, plantas e outros materiais. 2.ed. rev. e ampl. Porto Alegre: Universidade Federal do Rio Grande do Sul, 1995. 174p. (UFRGS. Departamento de Solos. Boletim técnico, 5).

WATTS, D.B.; TORBERT, H.A.; PRIOR, S.A.; HULUKA, G. Long-term tillage and poultry litter impacts soil carbon and nitrogen mineralization and fertility. Soil Fertility and Plant Nutrition, v.74, p.1239-1247, 2010. DOI:10.2136/sssaj2008.0415.

ZHANG, J.B.; ZHU, T.B.; CAI, Z.C.; QIN, S.W.; MÜLLER, C. Effects of long-term repeated mineral and organic fertilizer applications on soil nitrogen transformations. European Journal of Soil Science, v.63, p.75-85, 2011. DOI: 10.1111/j.13652389.2011.01410.x.

Received on May 14, 2017 and accepted on June 4, 2017 